\title{
Immunologic Effects of Background Prenatal and Postnatal Exposure to Dioxins and Polychlorinated Biphenyls in Dutch Infants
}

\author{
NYNKE WEISGLAS-KUPERUS, THEO C. J. SAS, CORINE KOOPMAN-ESSEBOOM, \\ CEES W. VAN DER ZWAN, MARIA A. J. DE RIDDER, AUKE BEISHUIZEN, \\ HERBERT HOOIJKAAS, AND PIETER J. J. SAUER \\ Department of Pediatrics, Division of Neonatology, Erasmus University and University Hospital/Sophia \\ Children's Hospital, Rotterdam, The Netherlands [N.W.-K., T.C.J.S, C.K.-E., P.J.J.S.]; Department of \\ Immunology, Erasmus University and University Hospital, Rotterdam, The Netherlands [H.H., A.B.]; \\ Department of Infectious Diseases Epidemiology, National Institute of Public Health and Environmental \\ Protection, Bilthoven, The Netherlands [C.W.v.d.Z]; Institute of Epidemiology and Biostatistics, Erasmus \\ University, Rotterdam, The Netherlands [M.A.J.d.R.]
}

\begin{abstract}
Immunologic effects of pre- and postnatal polychlorinated biphenyl (PCB)/dioxin exposure in Dutch infants from birth to 18 mo of age are explored. The total study group consisted of 207 healthy mother-infant pairs, of which 105 infants were breast-fed and 102 children were bottle-fed. Prenatal PCB exposure was estimated by the PCB sum (PCB congeners 118, 138, 153, and 180 ) in maternal blood and the total toxic equivalent (TEQ) level in human milk (17 dioxin and 8 dioxin-like PCB congeners). Postnatal PCB/dioxin exposure was calculated as a product of the total TEQ level in human milk multiplied by the weeks of breast-feeding. The number of periods with thinitis, bronchitis, tonsillitis, and otitis during the first 18 mo of life was used as an

infants. There was no relationship between pre-and postnatal $\mathrm{PCB} /$ dioxin exposure and upper or lower respiratory tract symptoms or humoral antibody production. A higher prenatal PCB/ dioxin exposure was associated with an increase in the number of $\mathrm{TcR} \gamma \delta^{+} \mathrm{T}$ cells at birth and with an increase in the total number of $\mathrm{T}$ cells and the number of $\mathrm{CD} 8^{+}$(cytotoxic), $\mathrm{TcR} \alpha \beta^{+}$, and $\mathrm{TcR} \gamma \delta^{+} \mathrm{T}$ cells at 18 mo of age. A higher prenatal as well as postnatal $\mathrm{PCB} /$ dioxin exposure was associated with lower monocyte and granulocyte counts at 3 mo of age. In conclusion, our study suggests that background levels of $\mathrm{PCB} /$ dioxin exposure influences the human fetal and neonatal immune system. (Pediatr Res 38: 404-410, 1995)
\end{abstract} estimate of the health status of the infants. Humoral immunity was measured at 18 mo of age by detecting antibody levels to mumps, measles, and rubella. White blood cell counts (monocytes, granulocytes, and lymphocytes) and immunologic marker analyses $\mathrm{CD} 4^{+} \mathrm{T}$-lymphocytes, $\mathrm{CD} 8^{+} \mathrm{T}$-lymphocytes, activated T-lymphocytes (HLA-DR ${ }^{+} \mathrm{CD}^{+}$), as well as $\mathrm{T}$ cell receptor (TcR) $\alpha \beta^{+}, \mathrm{TcR} \gamma \delta^{+}, \mathrm{CD}^{+}{ }^{+} \mathrm{CD} 45 \mathrm{RA}^{+}$and $\mathrm{CD} 4^{+} \mathrm{CD} 45 \mathrm{RO}^{+}$ T-lymphocytes, B-lymphocytes $\left(\mathrm{CD} 19^{+}\right.$and/or $\left.\mathrm{CD} 20^{+}\right)$and $\mathrm{NK}$ cells $\left(\mathrm{CD} 16^{+}\right.$and/or $\left.\mathrm{CD} 56^{+} / \mathrm{CD}^{-}\right)$in cord blood and venous blood at 3 and 18 mo of age were assessed in a subgroup of 55

Prenatal and postnatal exposure to PCDD, PCDF, and PCB produce a wide spectrum of toxic effects in animals, including body weight loss, hepatotoxicity, teratogenicity, carcinogenicity, neurotoxicity, reproductive toxicity, alterations in the thy-

Received December 8, 1994; accepted April 27, 1995.

Manuscript dedicated to Professor H. K. A. Visser in honor of his retirement. Correspondence: N. Weisglas-Kuperus, Department of Pediatrics, Division of Nennatology, Erasmus University and University Hospital Rotterdam/Sophia Children's Hospital, Dr. Molewaterplein 60, 3015 G.J Rotterdam, The Netherlands.

Supported by the Dutch Toxicology Research Promotion Program and the Health Research Stimulation Program.

\author{
Abbreviations \\ PCDD, polychlorinated dibenzo- $p$-dioxin \\ PCDF, polychlorinated dibenzofuran \\ PCB, polychlorinated biphenyl \\ TCDD, 2,3,7,8 tetrachlorodibenzo- $p$-dioxin \\ TCDF, 2,3,7,8 tetrachlorodibenzofuran \\ TEQ, toxic equivalent \\ TcR, T cell receptor \\ NK, natural killer
}

roid hormone status (1), and immunotoxicity. Many animal studies have shown adverse effects of PCDD, PCDF (summarized as dioxins), and $\mathrm{PCB}$ on the immune system. The most consistent finding in these studies is thymic atrophy (2-5). In utero and lactational exposure is a more sensitive period for the immunotoxic effects than adult exposure, suggesting that during maturation the immune system is particularly sensitive to these compounds.

Most studies were conducted in mice in which the adult, as well as the fetus, is very sensitive to immunotoxic effects. There is evidence that perinatal TCDD exposure produces an 
alteration in the normal thymocyte maturation process (5-10). In addition a direct effect on the fetal liver and neonatal bone marrow has been shown $(2,7,8)$. TCDD and TCDF may also interfere with $\mathrm{B}$ cell maturation and with humoral antibody production (11-14). In addition an increased activity of NK cells has been found (15). A decrease in thymus weight and alterations in $\mathrm{T}$ cell differentiation, however, were also found in TCDD exposed rats $(4,16)$ and a reduction in thymocytes in the offspring of PCB exposed pregnant minks (17). Neubert et al. $(18,19)$ found changes in the number of B cell, NK cell, and $\mathrm{T}$ cell subpopulations in venous blood of marmosets treated with low doses of TCDD. In seals fed on PCDD-, PCDF-, and PCB-polluted herrings, lower NK and $\mathrm{T}$ cell activity was found. In addition there were higher levels of circulating polymorphonuclear granulocytes, which may suggest an increase in the occurrence of bacterial infections (20).

Data regarding the potential toxic effects of PCDD, PCDF, and $\mathrm{PCB}$ on the immune system in human beings are scarce. In vitro studies of human venous blood and lymphocyte fractions incubated with low doses of TCDD demonstrated a decrease in $\mathrm{B}$ cells and $\mathrm{CD}^{+}$(helper) $\mathrm{T}$ cells and an increase in $\mathrm{CD} 8^{+}$ (cytotoxic) $\mathrm{T}$ cells (21). The first indication that $\mathrm{PCB}$ and dioxins might be immunotoxic in vivo came from studies in accidentally exposed humans (22-29). In highly industrialized, densely populated Western European countries, like the Netherlands, dioxin levels in human milk samples can be especially high (10-100 pg TEQ/g milk fat). Whether prenatal and postnatal exposure to these high background levels of PCDD, $\mathrm{PCDF}$, and $\mathrm{PCB}$ can alter the immune system in human infants and whether the health of the infant is adversely affected by these pollutants is not known. In this report we explore the immunologic effects of environmental prenatal and postnatal background exposure to PCDD, PCDF, and PCB in infants from birth to 18 mo of age. This study is part of the Dutch PCB/Dioxin Study, a larger prospective longitudinal study on possible adverse health effects of these pollutants on human infants.

\section{METHODS}

Subjects. The total study group consisted of 207 healthy mother-infant pairs, recruited between June 1990 and February 1992, living in the Rotterdam area and was described in detail in a previous paper (30). All mother-infant pairs were of the Caucasian race. Pregnancy and delivery had to be completed without overt signs of serious illness or complications. Only infants born at term ( 37 to $42 \mathrm{wk}$ of gestation) without congenital anomalies or diseases were included. A hundred and five infants were breast-fed for at least $6 \mathrm{wk}, 102$ infants were exclusively bottle-fed with Almiron M2 from one batch (Nutricia N.V., The Netherlands). A description of the characteristics of the total study group is presented in Table 1.

In a subgroup of infants, recruited between March 1991 and February 1992, white blood cell counts and immunologic marker analyses in cord and venous blood at 3 and 18 mo of age were done. Because fresh blood is needed for these measurements, only infants born on a weekday and living close to the hospital were included in this part of the study. A descrip-
Table 1. Description of the characteristics and potential confounders of the total study group $(n=207)$ and the subgroup

\begin{tabular}{|c|c|c|}
\hline Variables and categories & $\begin{array}{l}\text { Total group } \\
(n=207)\end{array}$ & $\begin{array}{l}\text { Subgroup } \\
(n=55)\end{array}$ \\
\hline Maternal and socio-demographic variables & $\%$ & $\%$ \\
\hline \multicolumn{3}{|l|}{ Maternal education } \\
\hline Low & 19 & 13 \\
\hline Medium & 61 & 62 \\
\hline High & 20 & 25 \\
\hline \multicolumn{3}{|l|}{ Paternal occupation } \\
\hline Low & 59 & 64 \\
\hline Medium & 11 & 6 \\
\hline High & 30 & 30 \\
\hline \multicolumn{3}{|l|}{ Smoking during pregnancy } \\
\hline No & 77 & 84 \\
\hline Yes & 23 & 16 \\
\hline \multicolumn{3}{|l|}{ Alcohol during pregnancy } \\
\hline No & 83 & 84 \\
\hline Yes & 17 & 16 \\
\hline \multicolumn{3}{|l|}{ Infant variables } \\
\hline \multicolumn{3}{|l|}{ Sex } \\
\hline Male & 54 & 60 \\
\hline Female & 46 & 40 \\
\hline \multicolumn{3}{|l|}{ Type of feeding } \\
\hline Breast & 52 & 50 \\
\hline \multirow[t]{2}{*}{ Formula } & 48 & 50 \\
\hline & Mean (SD) & Mean (SD) \\
\hline Duration of breast feeding (wk) & $20.4(13.6)$ & $21.1(13.1)$ \\
\hline Gestational age (wk) & $40.5(1.2)$ & $40.2(1.1)$ \\
\hline Birth weight $(\mathrm{g})$ & $3465(443)$ & $3534(338)$ \\
\hline Weight/length, 3 mo $(\mathrm{g} / \mathrm{cm})$ & $97.7(9.7)$ & $98.1(8.2)$ \\
\hline Weight/length, 18 mo $(\mathrm{g} / \mathrm{cm})$ & $145.1(14.4)$ & $145.6(13.4)$ \\
\hline
\end{tabular}

tion of the characteristics of the subgroup in comparison to the total group is presented in Table 1 . In 48 infants cord blood was analyzed. At 3 mo of age, in 1 of the original 48 children the venipuncture was not successful, and a randomly chosen child was added to the study group. At 18 mo of age fresh blood was available for analysis in 37 of the original 48 children, and 6 randomly chosen children were added. There were no significant differences between the total study group and the subgroup.

Measures of PCB/dioxin exposure. A blood sample was taken from the mothers in the last month of pregnancy (36 to $40 \mathrm{wk}$ ) and analyzed by GC with electron capture detection for the measurement of four PCB congener levels (PCB 118, 138, 153, and 180). The four congener levels were added and summarized as the PCB-plasma-sum. One blood sample was missing for this analysis. In the second week after delivery, the breast-feeding mothers collected a 24 -h representative human milk sample with a vacuum pump (KAWECO, Babyluxus 2, Stuttgart, Germany). Seventeen individual dioxin congener and $24 \mathrm{PCB}$ congener levels were measured. Congener specific analyses of PCDD, PCDF, and PCB were carried out using previously described methods (31). The international toxic equivalence factor approach was used for PCDD and PCDF (32) and the WHO 1993 approach for PCB (33). According to the TEQ concept, a toxic equivalent factor was assigned to the 17 dioxin and 8 dioxin-like (planar, mono-ortho and di-ortho) PCB congeners. By multiplying the concentration (pg/g milk fat) and the toxic equivalence factor value, a TEQ value of 
each congener was calculated (pg TEQ/g milk fat). The TEQsum of the 17 dioxin, 3 planar PCB $(77,126,169), 3$ monoortho PCB $(105,118,156)$, and 2 di-ortho PCB $(170,180)$ congeners were summarized as the total TEQ level. Of the 105 human milk samples, 80 could be measured with sufficient accuracy for the total TEQ level. The other analytical measurements were inaccurate due to interferences in the chromatograms, or due to too small volumes of human milk samples and therefore excluded from further analyses. As a measure of prenatal exposure, the PCB-plasma-sum of all individual mother-infant pairs was used. For the breast-fed infants the total TEQ level in human milk was separately studied as an estimate of the prenatal exposure. Postnatal PCB/dioxin exposure was calculated as a product of the total TEQ level in human milk, multiplied by weeks of breast-feeding.

Measures of immunologic effects. All parents were asked to complete a health questionnaire regarding their infant. The number of periods with rhinitis, bronchitis, tonsillitis, and otitis during the first 18 mo of life was counted and used as an estimate of the health status of the infants.

Vaccinations against mumps, measles, and rubella were given to 205 of the 207 children at approximately 14 mo of age as part of the National Immunization Program. The vaccines were given at the local municipal health service. Humoral antibody production was measured at 18 mo of age by detecting antibody levels to mumps, measles, and rubella in plasma with an ELISA (34).

Monocyte, granulocyte, and lymphocyte counts were determined by whole blood fluorescence-activated cell sorter analysis combined with the determination of the white blood cell count by a cell counter (35). Using several MAb, absolute numbers of the following lymphocyte (sub)populations were determined: $\mathrm{CD}^{+}{ }^{+}$T-lymphocytes $\left(\mathrm{CD} 4^{+} \mathrm{CD} 3^{+}\right), \mathrm{CD}^{+} \mathrm{T}$ lymphocytes $\left(\mathrm{CD} 8^{+} \mathrm{CD}^{+}\right)$, activated T-lymphocytes (HLA$\left.\mathrm{DR}^{+} \mathrm{CD}^{+}\right)$, as well as TcR $\alpha \beta^{+}, \mathrm{TcR} \gamma \delta^{+}, \mathrm{CD} 4^{+} \mathrm{CD} 45 \mathrm{RA}^{+}$ and $\mathrm{CD} 4^{+} \mathrm{CD} 45 \mathrm{RO}^{+}$T-lymphocytes, B-lymphocytes $\left(\mathrm{CD} 19^{+}\right.$ and/or $\left.\mathrm{CD} 20^{+}\right)$, and $\mathrm{NK}$ cells $\left(\mathrm{CD}_{16}{ }^{+}\right.$and/or $\left.\mathrm{CD} 56^{+} / \mathrm{CD}^{-}\right)$.

Data analysis. Data analysis was performed using the statistical software package SPSS win 6.01. The relationship between immunologic parameters and $\mathrm{PCB} /$ dioxin exposure was studied in univariate analyses ( $t$ test, $\chi^{2}$ test, and Spearman correlation coefficient). In a first analysis prenatal (PCBplasma-sum and total TEQ) and postnatal (total TEQ multiplied by weeks of breast-feeding) PCB-dioxin exposure were studied in relation to the immunologic parameters. When the PCB-plasma-sum was significantly correlated ( $p \leq 0.05$,) with the outcome variable, analyses of the separate PCB congener levels 118, 138, 153, and 180 in maternal plasma were done. When the total TEQ was significantly correlated with the outcome variable, analyses of the dioxin and dioxin-like (planar, mono-ortho, and di-ortho) PCB congeners in human milk were done. Potential confounding variables at birth (birth weight, gestational age, sex, smoking and alcohol use during pregnancy, maternal education, and paternal occupation) and at 3 and 18 mo of age (sex, nutritional status, duration of breastfeeding, maternal education, and paternal occupation) were selected, according to clinical and immunologic knowledge. Potential confounding variables were analyzed when the PCB/ dioxin exposure was significantly correlated with the outcome variable.

The study protocol had been approved by the medical ethical committee of the University Hospital Rotterdam/Sophia Children's Hospital. Informed consent had been given by the parents.

\section{RESULTS}

The mean PCB-plasma-sum in the total group was 2.25 $\mu \mathrm{g} / \mathrm{L}(\mathrm{SD} 0.98, n=206)$ and the mean total TEQ level was $66.59 \mathrm{pg} / \mathrm{g}$ fat (SD 24.35, $n=80$ ). The mean PCB-plasma-sum in the subgroup was $2.10 \mu \mathrm{g} / \mathrm{L}$ (SD 0.87, $n=55$ ) and the mean total TEQ was $64.20 \mathrm{pg} / \mathrm{g}$ fat (SD 19.08, $n=19$ ). There were no significant differences in the mean PCB-plasma-sum or total TEQ level between the total group and the subgroup.

There were no significant correlations between the number of periods with rhinitis, bronchitis, tonsillitis, and otitis during the first 18 mo of life and prenatal (PCB-plasma-sum and total TEQ level) and postnatal (total TEQ level multiplied by the number of breast-feeding weeks) PCB/dioxin exposure. There were also no significant correlations between the specific antibody levels to mumps, measles, and rubella at 18 mo of age and pre- and postnatal $\mathrm{PCB} /$ dioxin exposure.

The results of the white blood cell counts and the immunologic marker analyses in cord blood and venous blood at 3 and 18 mo of age are presented in Table 2 . The results are all within the normal ranges in age-matched children. Correlations between the different leukocyte (sub)populations and pre- and postnatal PCB/dioxin exposure are presented in Table 3.

At birth a higher total TEQ level was correlated with an increase in $\mathrm{TcR} \gamma \delta^{+} \mathrm{T}$ cells $(p=0.03)$. Correlation coefficients with the dioxin, planar, mono-ortho, and di-ortho PCB congeners only reached statistical significance for the dioxin TEQ level (Table $4, p=0.01$ ). There were no significant correlations between the number of $\mathrm{TcR} \gamma \delta^{+} \mathrm{T}$ cells and the potential confounders.

At 3 mo of age a higher total TEQ level was significantly correlated with a decrease in the number of monocytes ( $p=$ $0.003)$ and granulocytes $(p=0.04)$. A higher postnatal exposure was significantly correlated with a decrease in the total number of monocytes $(p=0.03)$, granulocytes $(p=0.01)$, and B-cells $(p=0.05)$. The monocyte count was significantly correlated with the dioxin TEQ level $(p=0.01)$, the monoortho ( $p=0.002)$, and di-ortho $(p=0.03)$ PCB TEQ level. The granulocyte count was significantly correlated only with the total TEQ level; correlation coefficients with the dioxin, planar, mono-ortho, and di-ortho PCB congener levels did not reach statistical significance (Table 4). There was no significant correlation between the monocyte and granulocyte counts and the potential confounders. The number of CD19/20 ${ }^{+}$cells was significantly correlated with the duration of breast-feeding $\left(r_{\mathrm{S}}=0.64, p=0.003\right)$.

At 18 mo of age higher total TEQ and PCB-plasma-sum levels were significantly correlated with an increase in the number of $\mathrm{CD}^{+} \mathrm{T}$ cells (PCB-plasma-sum, $p=0.01$, total TEQ, $p=0.002)$. In maternal plasma PCB $118\left(r_{\mathrm{S}}=0.33, p=\right.$ $0.03)$, PCB $138\left(r_{\mathrm{S}}=0.32, p=0.04\right), \mathrm{PCB} 153\left(r_{\mathrm{S}}=0.37\right.$, 
Table 2. Results of the white blood cell counts and the immunologic marker analyses in cordblood and venous blood at 3 and 18 months

\begin{tabular}{|c|c|c|c|c|c|c|c|c|c|}
\hline \multirow[b]{2}{*}{ Cells } & \multicolumn{3}{|c|}{$\begin{array}{c}\text { Cord blood } \\
n=48 \\
\text { (percentiles, } 10^{6} / \mathrm{L} \text { ) }\end{array}$} & \multicolumn{3}{|c|}{$\begin{array}{c}3 \mathrm{mo} \\
n=48 \\
\text { (percentiles, } 10^{6} / \mathrm{L} \text { ) }\end{array}$} & \multicolumn{3}{|c|}{$\begin{array}{c}18 \text { mo } \\
n=43 \\
\text { (percentiles, } 10^{6} / \mathrm{L} \text { ) }\end{array}$} \\
\hline & $\mathrm{p} 25$ & p50 & p75 & p25 & p50 & $\mathrm{p} 75$ & $\mathrm{p} 25$ & p50 & $\mathrm{p} 75$ \\
\hline \multicolumn{10}{|l|}{ White blood cell counts } \\
\hline Monocytes & 925 & 1200 & 1675 & 600 & 700 & 900 & 500 & 700 & 800 \\
\hline Granulocytes & 5500 & 7000 & 9625 & 2025 & 2550 & 3575 & 3000 & 3400 & 5100 \\
\hline Lymphocytes & 3000 & 4000 & 4600 & 4425 & 5600 & 6575 & 3900 & 5300 & 6300 \\
\hline \multicolumn{10}{|l|}{$\mathrm{T}$ cell markers } \\
\hline $\mathrm{CD}^{+}$ & 1554 & 2088 & 2610 & 2749 & 3845 & 4358 & 2410 & 3340 & 4060 \\
\hline $\mathrm{CD}^{+}{ }^{+} \mathrm{CD} 4^{+}$ & 1035 & 1448 & 1945 & 1995 & 2805 & 3509 & 1505 & 1950 & 2620 \\
\hline $\mathrm{CD}^{+} \mathrm{CD}^{+}$ & 265 & 480 & 730 & 643 & 940 & 1203 & 800 & 1110 & 1490 \\
\hline 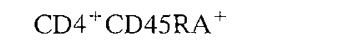 & 450 & 760 & 1500 & 1488 & 1930 & 2645 & 1040 & 1.420 & 1835 \\
\hline $\mathrm{CD}^{+}{ }^{+} \mathrm{CD} 45 \mathrm{RO}^{+}$ & 40 & 60 & 190 & 130 & 160 & 228 & 180 & 290 & 350 \\
\hline $\operatorname{TcR} \alpha \beta^{+}$ & 1375 & 1960 & 2370 & 2545 & 3535 & 4180 & 2270 & 3030 & 3790 \\
\hline $\operatorname{TcR} \gamma \delta^{+}$ & 30 & 40 & 60 & 100 & 120 & 170 & 140 & 230 & 300 \\
\hline $\mathrm{CD}^{+}{ }^{+}$HLA-DR ${ }^{+}$ & 40 & 50 & 108 & 160 & 225 & 328 & 180 & 290 & 410 \\
\hline \multicolumn{10}{|l|}{ B cell marker } \\
\hline CD 19/20+ & 314 & 550 & 773 & 1105 & 1448 & 1943 & 1050 & 1280 & 1875 \\
\hline \multicolumn{10}{|l|}{ NK cell marker } \\
\hline $\mathrm{CD} 16^{+}$and $/$or $\mathrm{D}^{2} 6^{+} / \mathrm{CD}^{-}$ & 533 & 785 & 1225 & 260 & 350 & 548 & 230 & 340 & 608 \\
\hline
\end{tabular}

Table 3. Spearman rank correlation coefficients of the white blood cell counts and the immunological marker analyses in cordblood and venous blood at 3 and 18 mo of age in relation with $P C B /$ dioxin exposure

\begin{tabular}{|c|c|c|c|c|c|c|c|c|}
\hline \multirow{3}{*}{ Cells } & \multicolumn{8}{|c|}{ Spearman rank correlation coefficient after $\mathrm{PCB} /$ dioxin exposure } \\
\hline & \multicolumn{2}{|c|}{ Cordblood } & \multicolumn{3}{|c|}{$3 \mathrm{mo}$} & \multicolumn{3}{|c|}{$18 \mathrm{mo}$} \\
\hline & $\begin{array}{l}\text { Prenatal } \\
(n=48) \\
\text { PCB sum }\end{array}$ & $\begin{array}{c}\text { Prenatal } \\
(n=19) \\
\text { Total TEQ }\end{array}$ & $\begin{array}{l}\text { Prenatal } \\
(n=48) \\
\text { PCB sum }\end{array}$ & $\begin{array}{c}\text { Prenatal } \\
(n=19) \\
\text { Total TEQ }\end{array}$ & $\begin{array}{c}\text { Postnatal } \\
(n=19) \\
\text { TEQ } \times \text { wk }\end{array}$ & $\begin{array}{l}\text { Prenatal } \\
(n=43) \\
\text { PCB sum }\end{array}$ & $\begin{array}{c}\text { Prenatal } \\
(n=12) \\
\text { Total TEQ }\end{array}$ & $\begin{array}{c}\text { Postnatal } \\
(n=12) \\
\text { TEQ } \times \text { wk }\end{array}$ \\
\hline \multicolumn{9}{|l|}{ White cell blood counts } \\
\hline Monocytes & -0.06 & -0.18 & -0.03 & $-0.64 * *$ & $-0.49 *$ & 0.06 & 0.23 & 0.12 \\
\hline Granulocytes & -0.07 & -0.27 & -0.07 & $-0.47^{*}$ & $-0.55^{*}$ & 0.02 & 0.09 & 0.27 \\
\hline Lymphocytes & -0.03 & -0.06 & -0.10 & -0.42 & -0.40 & 0.09 & 0.36 & 0.06 \\
\hline \multicolumn{9}{|l|}{$\mathrm{T}$ cell markers } \\
\hline $\mathrm{CD}^{+}$ & 0.02 & 0.07 & 0.02 & -0.07 & -0.10 & 0.19 & 0.47 & 0.20 \\
\hline $\mathrm{CD} 3^{+} \mathrm{CD} 4^{+}$ & -0.07 & 0.01 & -0.02 & -0.05 & -0.05 & 0.12 & 0.43 & 0.20 \\
\hline $\mathrm{CD}^{+} \mathrm{CD}^{+}$ & 0.14 & 0.17 & 0.10 & -0.02 & 0.03 & $0.38^{*}$ & $0.65^{*}$ & 0.34 \\
\hline $\mathrm{CD}^{+}{ }^{+} \mathrm{CD} 45 \mathrm{RA}^{+}$ & -0.17 & 0.19 & -0.08 & 0.01 & 0.01 & -0.01 & 0.33 & 0.25 \\
\hline $\mathrm{CD} 4{ }^{+} \mathrm{CD} 45 \mathrm{RO}^{+}$ & -0.05 & 0.39 & 0.07 & 0.06 & 0.01 & 0.23 & 0.19 & -0.22 \\
\hline $\operatorname{TcR} \alpha \beta^{+}$ & -0.01 & 0.10 & -0.01 & -0.09 & -0.11 & 0.20 & $0.57^{*}$ & 0.24 \\
\hline $\operatorname{TcR} \gamma \delta^{+}$ & 0.18 & $0.50^{*}$ & 0.13 & -0.10 & -0.06 & 0.22 & 0.43 & -0.10 \\
\hline $\mathrm{CD}^{+}{ }^{+}$HLA-DR $^{+}$ & -0.18 & -0.03 & 0.01 & -0.03 & -0.01 & 0.16 & 0.49 & -0.01 \\
\hline \multicolumn{9}{|l|}{ B cell marker } \\
\hline CD $19 / 20^{+}$ & -0.17 & -0.04 & -0.21 & -0.42 & $-0.45^{*}$ & -0.12 & 0.05 & -0.32 \\
\hline \multicolumn{9}{|l|}{ NK cell marker } \\
\hline $\mathrm{CD}_{16}{ }^{+}$and/or $\mathrm{CD}_{5} 6^{+} / \mathrm{CD}^{-}$ & 0.03 & 0.06 & 0.21 & -0.06 & 0.04 & 0.23 & 0.03 & -0.12 \\
\hline
\end{tabular}

$p=0.01)$ and $\mathrm{PCB} 180\left(r_{\mathrm{S}}=0.80, p=0.002\right)$ were significantly correlated with the number of $\mathrm{CD} 8^{+} \mathrm{T}$ cells. In human milk correlation coefficients with the dioxin, planar, monoortho, and di-ortho PCB congeners reached statistical significance for the dioxin TEQ level $(p=0.002)$ and the planar $(p=0.01)$ and di-ortho $(p=0.02)$ PCB TEQ levels (Table 4$).$ A higher total TEQ level was also significantly correlated with an increase in the number of $\mathrm{TcR} \alpha \beta^{+}$cells $(p=0.05)$. Correlation coefficients between the number of $\operatorname{TcR} \alpha \beta^{+}$cells and the dioxin, planar, mono-ortho and di-ortho PCB congeners reached statistical significance for the dioxin TEQ level $(p=0.009)$ and the di-ortho $(p=0.04)$ PCB TEQ level (Table
4). In addition a higher dioxin TEQ level was also significantly correlated with more $\mathrm{CD}^{+}\left(r_{\mathrm{S}}=0.61, p=0.04\right)$ and $\mathrm{TcR} \gamma \delta^{+}$ $\left(r_{\mathrm{S}}=0.70, p=0.01\right) \mathrm{T}$ cells. There were no significant correlations of the $\mathrm{T}$ cell markers at 18 mo of age with postnatal $\mathrm{PCB} /$ dioxin exposure nor with the potential confounders.

Comparing the number of periods with respiratory tract infections and the leukocyte (sub)population at 18 mo of age, there was a significant relationship only between the number of periods with bronchitis and the $\mathrm{CD}^{+}{ }^{+} \mathrm{CD} 45 \mathrm{RA}^{+} \mathrm{T}$-lymphocytes $\left(r_{\mathrm{S}}=0.33, p=0.04\right)$. Antibody levels to mumps were correlated with the total number of lymphocytes $\left(r_{\mathrm{S}}=0.32\right.$, 
Table 4. Spearman rank correlation coefficients of the significant correlations ( $p \leq .05)$ between the immunological parameters and the total TEQ: dioxin TEQ, planar, momo-ortho, and di-ortho PCB congener TEQ levels in breast milk

\begin{tabular}{|c|c|c|c|c|c|}
\hline \multirow[b]{2}{*}{ Cells } & \multicolumn{5}{|c|}{ Dioxin and dioxin-like PCB TEQ levels in breast milk: Spearman rank correlation coefficients } \\
\hline & Dioxin TEQ & Planar PCB TEQ & $\begin{array}{l}\text { Mono-ortho } \\
\text { PCB TEQ }\end{array}$ & $\begin{array}{l}\text { Di-ortho } \\
\text { PCB TEQ }\end{array}$ & Total TEQ \\
\hline \multicolumn{6}{|l|}{ White cell blood counts } \\
\hline Monocytes at $3 \mathrm{mo}$ & $-0.55 * *$ & -0.37 & $-0.67^{* *}$ & $-0.51 *$ & $-0.64 * *$ \\
\hline Granulocytes at 3 mo & -0.40 & -0.40 & -0.44 & -0.34 & $-0.47^{*}$ \\
\hline \multicolumn{6}{|l|}{$\mathrm{T}$ cell markers } \\
\hline $\mathrm{CD}^{+} \mathrm{CD}^{+}$at $18 \mathrm{mo}$ & $0.80^{* *}$ & $0.71 * *$ & 0.52 & $0.68 *$ & $0.65^{*}$ \\
\hline $\mathrm{TcR} \alpha \beta^{+}$at $18 \mathrm{mo}$ & $0.71^{* *}$ & 0.50 & 0.44 & $0.61 *$ & $0.57 *$ \\
\hline $\operatorname{TcR} \gamma \delta^{+}$in cord blood & $0.57 * *$ & 0.32 & 0.40 & 0.34 & $0.50^{*}$ \\
\hline
\end{tabular}

$*=p \leq 0.05$

$* *=p \leq 0.01$

$p=0.04)$, the $\mathrm{CD}^{+}\left(r_{\mathrm{S}}=0.33, p=0.04\right)$ and $\mathrm{TcR} \gamma \delta^{+}\left(r_{\mathrm{S}}=\right.$ $.37, p=0.02) \mathrm{T}$ - and the B-lymphocytes $\left(r_{\mathrm{S}}=0.32, p=0.05\right)$. Antibody levels to measles were significantly correlated with the number of $\mathrm{CD}^{+}\left(r_{\mathrm{S}}=0.35, p=0.03\right)$ and $\mathrm{TcR} \gamma \delta^{+}\left(r_{\mathrm{S}}=\right.$ $0.34, p=0.04)$ T-lymphocytes and with the NK cells $\left(r_{\mathrm{S}}=32\right.$, $p=0.05)$. Antibody levels to rubella were significantly correlated with the number of granulocytes $\left(r_{\mathrm{S}}=0.34, p=0.04\right)$ and the $\operatorname{TcR} \gamma \delta^{+}\left(r_{\mathrm{S}}=0.32, p=0.05\right)$ T-lymphocytes.

\section{DISCUSSION}

In this study two different effects of PCB/dioxin background exposure on the developing immune system of human infants were found. Prenatal PCB/dioxin exposure was associated with changes in $\mathrm{T}$ cell subpopulations in the blood. These changes were mainly seen at 18 mo of age. At that age a higher prenatal $\mathrm{PCB} /$ dioxin exposure was associated with an increase in the total number of $\mathrm{T}$ cells as well as with an increase in the number of $\mathrm{CD}^{+}$(cytotoxic), $\mathrm{TcR} \alpha \beta^{+}$and $\mathrm{TcR} \gamma \delta^{+} \mathrm{T}$ cells. These prenatal effects of $\mathrm{PCB} /$ dioxin exposure on changes in $\mathrm{T}$ cell subpopulations at a later age are consistent with findings in other human studies. In children born to mothers living in a TCDD-contaminated environment in Time Beach, MO, during and after pregnancy, a decrease in $\mathrm{CD} 4^{+}$(helper) $\mathrm{T}$ cells and an increase of $\mathrm{CD}^{+}$(cytotoxic) $\mathrm{T}$ cells has even been demonstrated at 9 to $14 \mathrm{y}$ of age (28). In one preliminary report from Northern Quebec, Inuit infants whose mothers have elevated levels of PCB and dioxins in their breast milk, the $\mathrm{CD}^{+}$(helper): $\mathrm{CD}^{+}$(cytotoxic) $\mathrm{T}$ cell ratio was decreased at 6 and 12 mo of age, but not at 3 mo of age (29). Our results are also in agreement with animal studies, where perinatal TCDD exposure produces an alteration in the normal thymocyte maturational process $(5,6)$. Moreover, in vitro studies of human venous blood and lymphocyte fractions incubated with TCDD demonstrated a decrease in $\mathrm{CD}^{+}$(helper) $\mathrm{T}$ cells and an increase in $\mathrm{CD}^{+}$(cytotoxic) $\mathrm{T}$ cells (21). In contrast to the above studies, we did not find a decrease in $\mathrm{CD}^{+}$(helper) $\mathrm{T}$ cells. All of these studies were, however, conducted in vitro or in higly exposed infants, whereas our study was conducted in background PCB/dioxin-exposed infants.

A higher prenatal as well as postnatal $\mathrm{PCB}$ /dioxin exposure was associated with lower monocyte and granulocyte counts only at 3 mo of age. The effects on the lymphocyte count fell short of statistical significance. Our findings are in agreement with animal studies where a direct effect on the fetal liver and neonatal bone marrow was found after perinatal dioxin exposure $(2,7,8)$. In Taiwan, in the Yucheng incident, changes in the monocyte maturational process were found in PCBpoisoned patients (23). Our results also agree with a previous study in Dutch infants where a negative correlation between dioxin concentrations in breast milk and the number of granulocytes was found at $1 \mathrm{wk}$ of age (36). Correlation coefficients of the monocyte and lymphocyte counts with prenatal PCB/ dioxin exposure were higher than with postnatal exposure. Correlation coefficients of the granulocyte count with prenatal $\mathrm{PCB} /$ dioxin exposure were lower than with postnatal exposure. Unfortunately due to the nonparametric distribution of the white blood cell counts and the small numbers of cases left, multivariate analysis was impossible.

A higher postnatal $\mathrm{PCB} /$ dioxin exposure was associated with a decrease in the number of CD $19 / 20^{+} \mathrm{B}$ cells. In the children, born to mothers living in TCDD-contaminated Time Beach, $\mathrm{MO}$, a decrease in $\mathrm{B}$ cells has also been demonstrated (28). Moreover, in vitro studies of human peripheral blood lymphocyte fractions incubated with TCDD showed a decrease of B cells (21). In our study group, however, the correlation coefficient of the number of $\mathrm{B}$ cells with the duration of breast feeding was higher than with postnatal $\mathrm{PCB}$ /dioxin exposure. We therefore presume that the decrease in $\mathrm{B}$ cells was mainly an effect of breast feeding. Further studies on the effect of breast feeding on the immune status of the infant are needed.

In our study there was no evidence of increased upper or lower respiratory tract symptoms or altered humoral antibody production in relation to $\mathrm{PCB} /$ dioxin exposure. Although there were differences in the leukocyte (sub)population between high and low $\mathrm{PCB} /$ dioxin-exposed infants, all values were within the normal range. Moreover, subtle changes in the number of blood leukocytes do not simply mirror alterations in the cell composition of lymphoid and nonlymphoid organs, nor do they simply reflect functional defects. In children born to accidentally highly exposed women, in the Yucheng incident, an increased incidence of respiratory symptoms was found (26). The Inuit infants, whose mothers had elevated levels of PCB and dioxins in their breast milk, experienced more episodes of acute otitis media at 3 to 6 mo of age (29). In a prospective longitudinal study of background PCB exposure in the United States, however, there was no adverse effect on the frequency 
of physician visits for various illnesses (37). The magnitude of the above described changes in the immune status of background-exposed infants associated with prenatal PCB/dioxin exposure, as compared with accidental high exposure, might be too subtle to induce these clinical symptoms. There are, however, some limitations to our health questionnaire. The number of periods with rhinitis, bronchitis, tonsillitis, and otitis was counted during the first 18 mo of life. No subdivision in shorter time periods was made. This might be the reason that we did not find a relationship between the number of respiratory infections and the leukocyte (sub)populations under study. There was, however, a significant relationship between the antibody levels and the number of $\mathrm{CD}^{+}$(cytotoxic) and $\operatorname{TcR} \gamma \delta$ T-lymphocytes at 18 mo of age. Therefore one might speculate that the lower numbers of monocytes and granulocytes at the age of 3 mo could have resulted in more (subclinical) infections during the first months of life and in an increase in the number of $\mathrm{CD}^{+}$(cytotoxic) $\mathrm{T}$ cells therafter.

The evaluation of $\mathrm{PCB} /$ dioxin exposure in human and environmental samples is difficult, because these compounds are complex mixtures of various related PCDD, PCDF, and PCB congeners. Effects associated with one type of congeners may therefore actually be due to another type of congeners. Moreover, some PCB congeners may antagonize the TCDDmediated immunotoxic effects (38). Samples of blood or breast milk obtained from the mother can be presumed to reflect her lifetime exposure. Cord blood provides the more direct measure of fetal exposure, but it is difficult to quantify the levels of the different PCB congeners because the fat content in cord blood is low. Given that PCB and dioxins are lipophilic, the PCB levels in cord blood are low (31). From a statistical standpoint, the poor reliability of measurement at these levels of exposure will tend to increase the likelihood of type II error and depress the magnitude of any effects associated with intra-uterine exposure to PCB (39). Breast milk and maternal plasma are easier to assess because of their higher lipid content. Because the PCB levels in maternal plasma correlate well with the PCB levels in umbilical cord plasma, and dioxin and PCB levels in human milk correlate well with the levels in adipose tissue (32), PCB/dioxin exposure was estimated from the levels of $\mathrm{PCB}$ in maternal plasma and the levels of dioxins and dioxin-like PCB in human milk.

In conclusion, this exploratory study is the first to show that background levels of $\mathrm{PCB} /$ dioxin exposure influences the human fetal and neonatal immune system. Although there is no evidence of clinical symptoms or direct changes in the humoral immunity response in infancy and the results of the white blood cell counts and immunologic marker analyses were all within the normal range, the described changes in the $T$ cell lymphocyte population could persist into later child- or adulthood and could presage difficulties, like immune suppression, allergy or autoimmunity (40). Follow-up of these children to adulthood is therefore needed. In the meantime the prevention of further environmental and food chain contamination is essential, along with their monitoring in various commodities.

Acknowledgment. The authors thank Dr. H. J. Aanstoot for critically reviewing this paper.

\section{REFERENCES}

1. Koopman-Esseboom C, Morse DC, Weisglas-Kuperus N, Lutkeschipholt IJ, van der Paauw CG, Tuinstra LGMT, Brouwer A, Sauer PJJ 1994 Effects on dioxins and polychlorinated biphenyls on thyroid hormone status og pregnant women and their infants. Pediatr Res 36:468-473

2. Fine JS, Gasiewicz TA, Fiore NC, Silverstone AE: 1990 Prothymocyte activity is reduced by perinatal 2,3,7,8-tetrachlorodibenzo- $p$-dioxin exposure. J Pharmacol Exp Ther 255:128-132

3. Dencker L, Hassoun E, d'Argy R, Alm G 1985 Fetal thymus organ culture as an in vitro model for the toxicity of $2,3,7,8$-tetrachlorodibenzo- $p$-dioxin and its congeners. Mol Pharmacol 27:133-140

4. Korte M, Stahlman R, Thiel R, Nagao T, Chaoud I, van Loveren H, Vos JG, Neubert D 1990 Effects of 2,3,7,8-terachlorodibenzo-p-dioxin on hepatic monooxygenases and resistance to trichinella spiralis infection in rat ofspring after perinatal exposure. In: Huntziger O, Fiedler H (eds) Organohalogen Compounds, Eco-Informa Press, Bayreuth, pp 89-94

5. Holladay SD, Lindstrom P, Blaylock BL, Comment CE, Germolec DR, Heindell JJ, Luster MI 1991 Perinatal thymocyte antigen expression and postnatal immune development altered by gestational exposure to tetrachlorodibenzo-p-dioxin (TCDD). Teratology 44:385-393

6. Blaylock BL, Holladay SD, Comment CE, Heindel JJ, Luster MI 1992 Exposure to tetrachlorodibenzo- $p$-dioxin (TCDD) alters fetal thyrnocyte maturation. Toxicol Appl Pharmacol 112:207-213

7. Fine JS, Gasiewicz TA, Silverstone AE 1989 Lymphocyte stem cell alterations following perinatal exposure to 2,3,7,8-tetrachlorodibenzo- $p$-dioxin. Mol Pharmacol $35: 18-25$

8. Ackermann MF, Gasiewicz TA, Lamm KR, Germolec DR, Luster MI 1989 Selective inhibition of polymorphonuclear neutrophil activity by 2,3,7,8-tetrachlorodibenzo-pdioxin. Toxicol Appl Pharmacol 101:470-480

9. Takagi Y, Aburada S, Otake T, Ikegami N 1987 Effect of polychlorinated biphenyls (PCBs) accumulated in the dam's body on mouse filial immunocompetence. Arch Environ Contam Toxicol 16:375-381

10. Tomar RS, Kerkvliet NI 1991 Reduced $\mathrm{T}$-helper cell function in mice exposed to 2,3,7,8-tetrachlorodibenzo-p-dioxin (TCDD). Toxicol Lett 57:55-64

11. Vecchi A, Sironi M, Canegrati MA, Recchia M, Garattini S 1983 Immunosuppressive effects of 2,3,7,8-tetrachlorodibenzo-p-dioxin in strains of mice with different susceptibility to induction of aryl hydrocarbon hydroxylase. Toxicol Appl Pharmacol $68: 434-441$

12. Luster MI, Germolec DR, Clark G, Wiegand G, Rosenthal GJ 1988 Selective effects of $2,3,7,8$-tetrachlorodibenzo-p-dioxin and corticosteroid on in vitro lymphocyte maturation. J Immunol 140:928-935

13. Tucker AN, Vore SJ, Luster MI 1986 Suppression of B cell differentiation by 2,3,7,8-tctrachlorodibenzo- $p$-dioxin. Mol Pharmacol 29:372-377

14. Clark GC, Blank JA, Germolec DR, Luster MI 1991 2,3,7,8-Tetrachlorodibenzo-pdioxin stimulation of tyrosine phosphorylation in B lymphocytes: Potential role in immunosuppression. Mol Pharmacol 39:495-501

15. Funseth E, rlback NG 1992 Effects of 2,3,7,8-tetrachlorodibenzo-p-dioxin on blood and spleen natural killer (NK) cell activity in the mouse. Toxicol Lett 60:247-256

16. Smialowicz RJ, Riddle MM, Williams WC, Diliberto JJ 1994 Effects of 2,3,7,8tetrachlorodibenzo-p-dioxin (TCDD) on humoral immunity and lymphocyte subpopulations: Differences between mice and rats. Toxicol Appl Pharmacol 124:248256

17. Brunstrom B, Hakansson H, Lundberg K 1991 Effects of a technical PCB preparation and fractions thercof on ethoxyresorufin $O$-deethylasc activity, vitamin $A$ levels and thymic development in the mink (Mustela vison). Pharmacol Toxicol 69:421-426

18. Neubert R, Jacob-Muller U, Stahlmann R, Helge H, Neubert D 1990 Polyhalogenated dibenzo-p-dioxins and dibenzofurans and the immune system. 1. Effects on peripheral lymphocyte subpopulations of a non-human primate (Callithrix jacchus) after treatment with 2,3,7,8-tetrachlorodibenzo-p-dioxin (TCDD). Arch Toxicol 64:345-359

19. Ncubert R, Golor G, Stahlmann R, Helge H, Neubert D 1992 Polyhalogenated dibenzo-p-dioxins and dibenzofurans and the immune system. 4. Effects of multipledose treatment with 2,3,7,8-tetrachlorodibenzo-p-dioxin (TCDD) on peripheral lymphocyte subpopulations of a non-human primate (Callithrix jacchus). Arch Toxicol $66: 250-259$

20. de Swart R, Ross PS, Vedder LJ, Timmerman HH, Heisterkamp S, van Loveren $H$, Vos JG, Reijnders PJH, Osterhaus ADME 1994 Impairment of immune function in harbor seals (Phoca vitulina) feeding on fish from polluted waters. Ambio 3:155-159

21. Neubert R, Jacob-Muller U, Helge H, Stahlmann R, Neubert D 1991 Polyhalogenated dibenzo-p-dioxins and dibenzofurans and the immune system. 2. In vitro effects of 2,3,7,8-tetrachlorodibenzo-p-dioxin (TCDD) on lymphocytes of venous blood from man and a non-human primate (Callithrix jacchus). Arch Toxicol 65:213-219

22. Shigematsu N, Ishimaru S, Saito R, Ikeda RT, Matsuba K, Sugiyama K, Masuda Y 1978 Respiratory involvement in polychlorinated biphenyls poisoning. Environ Res $16: 92-100$

23. Chang KJ, Hsieh KH, Lee TP, Tang SY, Tung TC 1982 Immunologic ecaluation of patients with polychorinated biphenyl poisoning: Determination of phagocyte Fc and complement receptors. Environ Res 28:329-334

24. Chang KJ, Hsieh KH, Lee TP, Tang SY, Tung TC 1981 Immunologic evaluation of patients with polychorinated biphenyl poisoning: Determination of lymphocyte subpopulations. Toxicol Appl Pharmacol 61:58-63

25. Chang KJ, Hsieh KH, Tang SY, Tung TC, Lee TP 1982 Immunologic evaluation of patients with polychorinated biphenyl poisoning: Hypersensitive response and its relation to clinical studies. J Toxicol Environ Health 9:217-223 
26. Rogan WJ, Gladen BC, Hung KL, Koong SL, Shih LY, Taylor JS, Wu YC, Yang D, Ragan NB, Hsu CC 1988 Congenital poisoning by polychlorinated biphenyls and their contaminants in Taiwan. Science 241:334-336

27. Hoffman RE, Stchr-Grcen PA, Wcbb KB, Evans RG, Knutsen AP, Schramm WF, Staakc JL, Gibson BB, Steinberg KK 1986 Health effects of long-term exposure to 2,3,7,8-tetrachlorodibenzo-p-dioxin. JAMA 255:2031-2038

28. Smoger GH, Kahn PC, Rodgers GC, Suffin S, McConnachie P 1993 In utero an postnatal exposure to 2,3,7,8-TCDD in Times Beach, Missouri. 1. Immunological effects; lymphocyle phenotype frequencics. Short paper In: Dioxin '93. 13th International Symposium on Clorinated Dioxins and Related Compounds, Vienna, pp 345-348

29. Dewailly E, Bruncau S, Laliberte C, Belles Iles M, Weber JP, Ayotte P, Roy R 1993 Brcast milk contamination by PCBs and PCDDs/PCDFs in Arctic Quebeq: Preliminary results on the immune status of Inuit infants. Short paper In: Dioxin '93. 13th International symposium on chlorinated dioxins and related compounds, Vienna, pp 403-406

30. Koupman-Esseboom C, Huisman M, Weisglas-Kuperus $N$, van der Paauw $C G$, Tuinstra LGMT, Boersma ER, Sauer PJJ 1994 PCB, dioxin levels in plasma and human milk of 418 Dutch women and their infants. Predictive value of PCB congener levels in maternal plasma for fetal and infant's exposure to PCBs and dioxins. Chemosphere 28:1721-1732

31. Tuinstra LGMT, Traag WA, van Rhijn JA, van de Spreng P 1994 The Dutch $\mathrm{PCB} /$ dioxin study. Development of a method for the determination of dioxins, planar and other PCBs in human milk. Chemosphere 29:1859-1875

32. NATO/CCMS 1988 Pilot study on international information exchange on dioxins and rclated compounds. International toxicity equivalency faclor (I-TEF). Methods of risk assessment for complex mixtures of dioxins and related compounds. Report No. 176
33. Ahlborg US, Bedring GC, Birnbaum LS 1994 Toxic equivalency factors for dioxinlike PCBs. Report on a WHO-ECEH, IPCS consultation, December 1993. Chemosphere 28:1049-1067

34. Harmsen $\mathrm{T}$, Jongerius $\mathrm{MC}$, van der $\mathrm{Z}$ wan $\mathrm{CW}$, Plantinga $\mathrm{AD}$, Kraaijeveld $\mathrm{CA}$ Berbers GA 1992 Comparison of a ncutralization enzyme immunoassay and an enzyme-linked immunosorbent assay for evaluation of immune status of children vaccinated for mumps. J Clin Microbiol 30:2139-2144

35. van de Merwe JP, van den Beemd MW, Hooijkaas H $1992 \mathrm{CDS}^{+}$B lymphocytes and other lymphocyle subsets in primary Sjogren's syndrome. Neth J Med 40:158-164

36. Pluim HJ 1993 Clinical laboratory manifestations of exposure to background levels of dioxins in the perinatal period. Dioxins, pre- and postnatal exposure in the human newborn, Thesis, Amsterdam University, Amsterdam, The Netherlands, pp 93-102

37. Rogan WJ, Gladen BC, McKinney JD, Carreras N, Hardy P, Thullen J, Tingelstad J, Tully M 1987 Polychlorinated biphenyls (PCBs) and dichlorodiphenyl dichlorocthene (DDE) in human milk: Effects on growth, morbidity, and duration of lactation. Am J Public Health 77:1294-1297

38. Davis D, Safe S 1989 Dose-response immunotoxicities of commercial polychlorinated biphenyls (PCBs) and their interaction with 2,3,7,8-tetrachlorodibenzo-p dioxin. Toxicol Lett 48:35-43

39. Jacobson JL, Jacobson SW 1994 The effects of perinatal exposure to polychlorinate biphenyls and related contaminants. In: Needleman HL, Bellinger D. (eds) Prenatal Exposure to Toxicants. Developmental Consequences. John Hopkins University Press, Baltimore, pp 130-147

40. Schuurman HJ, Van Loveren H, Rozing J, Vos JG 1992 Chemicals trophic for the thymus: risk for immunodeficiency and autoimmunity. Int J Immunopharmacol 14:369-375 